\title{
A test for 'hygienic' hand disinfection
}

\author{
G. A. J. AYliffe, J. R. BABB, AND A. H. QUORAISHI ${ }^{1}$ \\ From the Hospital Infection Research Laboratory, Dudley Road Hospital, Birmingham, UK
}

SUMMARY A standardised test procedure is described in which finger-tips are inoculated with broth cultures of organisms (Staphylococcus aureus, Staphyloccocus saprophyticus, Escherichia coli, and Pseudomonas aeruginosa): counts are made from washings of hands after disinfection with various antiseptic-detergents, alcoholic solutions, or unmedicated soap. $70 \%$ alcohol, with or without chlorhexidine, was the most effective preparation. The two antiseptic detergents showed variable results, but against Gram-negative bacilli neither was significantly more effective than plain soap. Some tests were also made on the death rate of organisms dried on the skin without disinfection.

Disinfection of the skin may be assessed either by measuring the reduction in numbers of natural (including resident) bacteria or of bacteria artificially applied to the skin, that is, transients (Price, 1938; Lowbury et al., 1964a; Männer et al., 1975). 'Hygienic hand disinfection' is now an accepted term in Europe for a method in which transient organisms are killed; the term 'surgical hand disinfection' is used to describe methods by which organisms of the resident flora are removed or killed. Transient bacteria, including Staphylococcus aureus or Gramnegative bacilli, are usually present on the skin in small numbers and can often be removed or reduced to very small numbers by washing with soap and water (Ayliffe et al., 1975). Nevertheless, in some circumstances, a higher degree of safety is required, and antiseptic preparations are needed for the reliable killing of transient organisms.

Although tests of effectiveness of disinfectants against artificially applied organisms have often been reported (Mittermayer and Rotter, 1975; Lowbury et al., 1964a), none has been accepted as a standard test for antiseptic or hygienic hand disinfection in the United Kingdom. This paper describes the development of a test modified from the official West German method (DGHM, 1972), in which the finger tips are inoculated with a broth culture of the test organism. The effect of various antiseptic detergent and alcoholic preparations on Staph. aureus, Staphylococcus saprophyticus, Pseudomonas aeruginosa, and Escherichia coli is assessed in two experiments, and the development of the test is described.

${ }^{1}$ Present address: Department of Medical Microbiology, Llandough Hospital, Cardiff

Received for publication 15 May 1978

\section{Methods and materials}

\section{APPLICATION OF TEST ORGANISMS}

Broth cultures of various challenge organisms were prepared by plating nutrient agar slope cultures on blood agar. After incubation five colonies were transferred to nutrient broth (Oxoid No. 2) and incubated for 18 hours at $37^{\circ} \mathrm{C}$.

To remove superficial transient bacteria volunteers washed their hands with non-medicated soap and water (social wash) and dried them thoroughly on paper towels. With the palms of the hand facing upwards and fingers outstretched, $0.02 \mathrm{ml}$ of the broth culture was applied to the tip of each finger and thumb with a '50 dropper' pasteur pipette and was spread by rubbing together opposing fingers and thumbs for 40 seconds. The process was completed by drying the fingers in the air, without rubbing, for another 80 seconds before sampling or disinfection.

\section{Test organisms}

Staph. aureus (1) NCTC 9716, Staph. aureus (2) NCTC 8354, Staph. saprophyticus (Baird Parker M3 Bio type 2, novobiocin resistant), Esch. coli (1) NCTC 8196, Esch. coli (2) Inst. Hygiene, Vienna, Ps. aeruginosa NCTC 6749, Serratia marcescens NCTC 2847, and an endemic strain of klebsiella serotype 21 from a urological ward.

\section{DISINFECTION AND WASHING OF HANDS}

Application of antiseptic detergents and liquid soap Two minutes after the application of the organisms, the hands were moistened under a running tap, and $5 \mathrm{ml}$ of the preparation was carefully poured into the cupped hands. The preparation was applied for 30 seconds by a standard procedure, consisting of five strokes backwards and forwards: palm to palm, 
right palm over left dorsum, left palm over right dorsum, palm to palm with fingers interlaced, backs of fingers to opposing palm with fingers interlocked, rotational rubbing of right thumb clasped over left palm and left thumb clasped over right palm, rotational rubbing backwards and forwards with clasped fingers of right hand in palm of left hand and clasped fingers of left hand in palm of right hand; hands and wrists were rubbed until the end of the 30-second period, then rinsed under a running tap for $\mathbf{1 5}$ seconds and dried, with two paper towels, for 15 seconds.

\section{Application of alcoholic preparations}

Five millilitres of the preparation was poured into the cupped hands and rubbed onto the skin for $\mathbf{3 0}$ seconds. The same procedure was used as with the detergents. Another period of 30 seconds was allowed before sampling to allow the hands to dry.

\section{RECOVERY AND CULTURE OF TEST \\ ORGANISMS}

Atter disinfection, the fingers and thumbs were immersed in $100 \mathrm{ml}$ of nutrient broth (Oxoid No. 2) with added neutralisers contained in a sterilised bowl (100 cm in diameter) and rubbed vigorously on $50 \mathrm{ml}$ of glass beads (3-5 mm diameter) for one minute. Neutralisers added to the broth were $0.75 \%$ lecithin-Tween mixture $(50 \mathrm{~g}$ Tween 80 and $5 \mathrm{~g}$ of lecithin) and $1 \%$ sodium thiosulphate. After sampling, the hands were rinsed, dried, and disinfected with $70 \%$ ethyl alcohol by the method already described. Ten millilitres of recovery broth was removed and thoroughly mixed on a rotary mixer, and $0.5 \mathrm{ml}$ quantities were transferred, by a $0.02 \mathrm{ml}$ dropping pipette, on to at least two well dried culture plates. Surface viable drop counts were made from these and appropriate 10-fold dilutions of the recovery broth. All plates were incubated at $37^{\circ} \mathrm{C}$ for 18 hours.

The following culture media were found suitable for the recovery of test organisms: blood agar (Oxoid Columbia agar base CM331 and 7.5\% horse blood) for Ps. aeruginosa, Esch. coli, $S$. marcescens, and Klebsiella spp, nutrient agar (Oxoid No. 2 broth with $1.2 \%$ New Zealand agar) containing $1 \%$ horse-serum and phenolphthalein disodiumphosphate (Barber and Kuper, 1951) for Staph. aureus, and nutrient agar containing $4 \mu \mathrm{g} / \mathrm{ml}$ novobiocin for Staph. saprophyticus.

SURVIVAL OF TEST ORGANISMS ON FINGERS Broth cultures of Staph. aureus, Esch. coli, Ps. aeruginosa, and Klebsiella spp were applied to the tips of fingers and thumbs as previously described. Fingers were sampled individually at two-minute intervals for up to 10 minutes by rubbing on glass beads in gallipots of broth for 30 seconds. Duplicates were obtained by sampling one finger from each hand after each time interval.

A series of tests was also made with the same organisms, and with Staph. saprophyticus and $S$. marcescens, in which all the fingers were sampled at two minutes in the manner previously described.

\section{Comparison of antiseptic preparations: 1}

Five preparations were compared by a latin square design of experiment (Lowbury et al., 1960). Six staff volunteers (three male and three female) took part in the experiment.

\section{Preparations}

1-unmedicated liquid soap

$2-4 \%$ chlorhexidine detergent (Hibiscrub)

3-7.5\% povidone-iodine surgical scrub (Betadine) $4-70 \%$ ethyl alcohol

$5-0.5 \%$ chlorhexidine gluconate (Hibitane) in $70 \%$ ethyl alcohol. The alcoholic preparations contained $1 \%$ glycerol as an emollient.

Six experiments were made on Tuesdays and Thursdays for 3 weeks. In every experiment all preparations were tested, and all subjects used each preparation once. Each subject was also left untreated in one of the six experiments. The application of test organisms and disinfectants and the recovery of organisms were as already described. Two series of experiments were made with the same preparations and volunteers, but with different organisms: Staph. aureus and Ps. aeruginosa.

Volunteers were asked to wash their hands between experiments with non-antiseptic preparations. If disinfection was required because of accidental contamination (most of the volunteers were laboratory staff), $70 \%$ ethyl alcohol containing $1 \%$ glycerol was used.

\section{Comparison of antiseptic preparations: 2}

Four preparations, unmedicated liquid soap, chlorhexidine detergent, povidone-iodine detergent, and $70 \%$ ethyl alcohol, were compared against various test organisms in groups of approximately 10 volunteers. The test organisms were Esch. coli 2, Staph. aureus 1 and 2, and Staph. saprophyticus. Experiments with Staph. aureus 1 were discontinued when two (one severe) of the volunteers developed sepsis due to the test strain, and a second strain, Staph. saprophyticus was used for subsequent tests. Whenever possible the same group of volunteers was used, but in this test method each person was his/her control for each preparation.

Test organisms were applied and recovered in the manner previously described, but a predisinfection 
sample was taken from each volunteer on completion of inoculation and drying. The hands were then rinsed under running water to remove the sampling broth, containing neutralisers, dried on two paper towels, and then reinoculated with the test organisms. On completion of the second inoculation and drying period the hands were washed or disinfected in the standard manner already described, and the surviving organisms were recovered. The mean logarithmic reduction of each test organism in the group of volunteers was used to compare the preparations.

\section{Results}

A large proportion of Esch. coli and Ps. aeruginosa applied to the fingers died during a period of 10 minutes (Table 1). Klebsiella showed a much greater survival, and the numbers of Staph. aureus remained almost unchanged after the initial period of drying of two minutes (Ricketts et al., 1951). All the cultures appeared to be visibly dry within two minutes, although this varied between 30 seconds and two minutes in different individuals. Table 2 confirms that an approximately 10 -fold reduction in these three organisms, $S$. marcescens, and Staph. saprophyticus occurs within two minutes.

The mean log counts after the various treatments, in the first comparative study, are shown in Tables 3 and 4. All treatments were significantly more effective than no treatment and both alcoholic solutions were significantly more effective than the antiseptic detergents. The antiseptic detergents were not significantly better than unmedicated soap in killing or removing Ps. aeruginosa.

An analysis of variance (Table 5) showed significant differences between treatments but not between experimental days in both series of experiments. The difference between persons was significant for Staph. aureus but not for Ps. aeruginosa.

Table 6 shows that consistent results were obtained for unmedicated soap and for $70 \%$ alcohol in the second study. Similar results were obtained in repeat tests on several of the preparations. $70 \%$ alcohol was significantly more effective than unmedicated soap, but other results were variable. Chlorhexidine detergent was significantly more effective than unmedicated soap or povidone-iodine against Staph. saprophyticus. Povidone-iodine was significantly more effective than unmedicated soap and chlorhexidine detergent against Staph. aureus. There was no significant difference between the antibacterial detergent preparations and unmedicated soap when $E$. coli 2 was the test organism. Isopropyl alcohol showed a similar reduction to $70 \%$ ethyl alcohol with Staph. saprophyticus as the test organism.

\section{Discussion}

In the development of a standard test method, several factors must be considered, for example, site and method of application of the organisms,

Table 1 Survival of test organisms on the skin of the finger-tips

\begin{tabular}{|c|c|c|c|c|c|c|c|}
\hline \multirow[t]{2}{*}{ Test organism } & & \multirow{2}{*}{$\begin{array}{l}\text { Initial } \\
\text { inoculum } \\
\text { (log count })\end{array}$} & \multicolumn{5}{|c|}{ Survivors (log counts) after: } \\
\hline & & & $2 \min ^{*}$ & $4 \min$ & $6 \mathrm{~min}$ & $8 \min$ & $10 \mathrm{~min}$ \\
\hline Staph. aureus (1) & $\begin{array}{l}\text { JB } \\
\text { WG }\end{array}$ & $\begin{array}{l}7 \cdot 36 \\
8 \cdot 23\end{array}$ & $\begin{array}{l}6 \cdot 92 \\
7 \cdot 11\end{array}$ & $\begin{array}{l}6.83 \\
7.04\end{array}$ & $\begin{array}{l}6 \cdot 50 \\
7 \cdot 15\end{array}$ & $\begin{array}{l}6 \cdot 66 \\
6 \cdot 84\end{array}$ & $\begin{array}{l}6.34 \\
6.04\end{array}$ \\
\hline Esch. coli & $\begin{array}{l}\text { JB } \\
\text { WG }\end{array}$ & $\begin{array}{l}7 \cdot 11 \\
7 \cdot 25\end{array}$ & $\begin{array}{l}7 \cdot 04 \\
6 \cdot 58\end{array}$ & $\begin{array}{l}5 \cdot 00 \\
5.93\end{array}$ & $\begin{array}{l}4 \cdot 78 \\
4 \cdot 83\end{array}$ & $\begin{array}{l}4 \cdot 30 \\
4 \cdot 75\end{array}$ & $\begin{array}{l}340 \\
4 \cdot 25\end{array}$ \\
\hline Ps. aeruginosa & $\begin{array}{l}\text { JB } \\
\text { WG }\end{array}$ & $\begin{array}{l}8 \cdot 15 \\
8 \cdot 30\end{array}$ & $\begin{array}{l}7.08 \\
7.00\end{array}$ & $\begin{array}{l}5.43 \\
5.67\end{array}$ & $\begin{array}{l}4.05 \\
6.25\end{array}$ & $\begin{array}{l}4 \cdot 50 \\
5 \cdot 32\end{array}$ & $\begin{array}{l}4 \cdot 72 \\
4 \cdot 95\end{array}$ \\
\hline Klebsiella spp. & $\begin{array}{l}\text { JB } \\
\text { WG }\end{array}$ & $\begin{array}{l}7 \cdot 52 \\
7 \cdot 52\end{array}$ & $\begin{array}{l}5.60 \\
6.63\end{array}$ & $\begin{array}{l}5.45 \\
6.06\end{array}$ & $\begin{array}{l}5 \cdot 15 \\
5 \cdot 81\end{array}$ & $\begin{array}{l}5.08 \\
5.85\end{array}$ & $\begin{array}{l}5 \cdot 11 \\
5 \cdot 85\end{array}$ \\
\hline
\end{tabular}

-In all cases visible drying had occurred before the two-minute sampling.

Table 2 Survival of test organisms on the fingers after two minutes

\begin{tabular}{|c|c|c|c|c|}
\hline Test organism & Mean initial log. count & Mean log. reduction after 2 min & No. of observations & No. of test person \\
\hline $\begin{array}{l}\text { S. marcescens } \\
\text { Ps. aeruginosa } \\
\text { Esch. coli } 1 \\
\text { Esch. coli } 2 \\
\text { Staph. aureus } 1 \\
\text { Staph. aureus } 2 \\
\text { Staph. saprophyticus }\end{array}$ & $\begin{array}{l}8 \cdot 48 \\
8 \cdot 48 \\
7 \cdot 94 \\
8 \cdot 27 \\
8 \cdot 84 \\
8 \cdot 35 \\
8 \cdot 16\end{array}$ & $\begin{array}{l}1.01 \\
0.82 \\
0.78 \\
1.53 \\
0.84 \\
0.85 \\
0.79\end{array}$ & $\begin{array}{l}5 \\
11 \\
18 \\
52 \\
11 \\
31 \\
65\end{array}$ & $\begin{array}{r}4 \\
8 \\
7 \\
14 \\
10 \\
15 \\
19\end{array}$ \\
\hline
\end{tabular}


Table 3 Viable counts (logs) of Staph. aureus from finger-tips

\begin{tabular}{|c|c|c|c|c|c|c|}
\hline \multirow[t]{2}{*}{ Expt. } & \multirow{2}{*}{$\begin{array}{l}\text { Initial log count } \\
\text { (no treatment) }\end{array}$} & \multicolumn{5}{|c|}{ Log counts after treatment with: } \\
\hline & & Soap & $\begin{array}{l}\text { Chlorhexidine } \\
\text { detergent }\end{array}$ & $\begin{array}{l}\text { Povidone-iodine } \\
\text { detergent }\end{array}$ & $70 \%$ ethyl alcohol & $\begin{array}{l}0.5 \% \text { alcoholic } \\
\text { chlorhexidine }\end{array}$ \\
\hline $\begin{array}{l}1 \\
2 \\
3 \\
4 \\
5 \\
6 \\
\text { Mean log count }\end{array}$ & $\begin{array}{l}7 \cdot 60 \text { (TB) } \\
7 \cdot 90(\mathrm{CD}) \\
7 \cdot 82(\mathrm{LG}) \\
7 \cdot 63(\mathrm{JB}) \\
7 \cdot 87(\mathrm{LT}) \\
8 \cdot 23(\mathrm{AQ}) \\
7 \cdot 84\end{array}$ & $\begin{array}{l}5 \cdot 80(\mathrm{JB}) \\
7 \cdot 34(\mathrm{LT}) \\
6.00(\mathrm{AQ}) \\
5 \cdot 70(\mathrm{~TB}) \\
5 \cdot 83(\mathrm{CD}) \\
6.00(\mathrm{LG}) \\
6.11\end{array}$ & $\begin{array}{l}6.18(\mathrm{AQ}) \\
5 \cdot 48(\mathrm{~TB}) \\
5 \cdot 66(\mathrm{CD}) \\
5 \cdot 28(\mathrm{LG}) \\
5 \cdot 25(\mathrm{JB}) \\
5 \cdot 48(\mathrm{LT}) \\
5 \cdot 55\end{array}$ & $\begin{array}{l}5 \cdot 23(\mathrm{LT}) \\
5 \cdot 23(\mathrm{AQ}) \\
3 \cdot 70(\mathrm{~TB}) \\
5 \cdot 06(\mathrm{CD}) \\
4 \cdot 48(\mathrm{LG}) \\
4 \cdot 15(\mathrm{JB}) \\
4 \cdot 64\end{array}$ & $\begin{array}{l}4.50(\mathrm{LG}) \\
4.04(\mathrm{JB}) \\
3.90(\mathrm{LT}) \\
3.00(\mathrm{AQ}) \\
4.28(\mathrm{~TB}) \\
4.48(\mathrm{CD}) \\
4.03\end{array}$ & $\begin{array}{l}4.40 \text { (CD) } \\
4.64 \text { (LG) } \\
3.60(\mathrm{JB}) \\
4.70(\mathrm{LT}) \\
3.58(\mathrm{AQ}) \\
2.90(\mathrm{~TB}) \\
3.97\end{array}$ \\
\hline
\end{tabular}

Initials of subjects are given in parentheses.

Table 4 Viable counts (logs) of Ps. aeruginosa from finger-tips

\begin{tabular}{|c|c|c|c|c|c|c|}
\hline \multirow[t]{2}{*}{ Expt. } & \multirow{2}{*}{$\begin{array}{l}\text { Initial log count } \\
\text { (no treatment) }\end{array}$} & \multicolumn{5}{|c|}{ Log counts after treatment with: } \\
\hline & & Soap & $\begin{array}{l}\text { Chlorhexidine } \\
\text { detergent }\end{array}$ & $\begin{array}{l}\text { Povidone-iodine } \\
\text { detergent }\end{array}$ & $70 \%$ ethyl alcohol & $\begin{array}{l}0.5 \% \text { alcoholic } \\
\text { chlorhexidine }\end{array}$ \\
\hline $\begin{array}{l}1 \\
2 \\
3 \\
4 \\
5 \\
6 \\
\text { Mean log count }\end{array}$ & $\begin{array}{l}7 \cdot 89(\mathrm{~TB}) \\
7 \cdot 04(\mathrm{CD}) \\
7 \cdot 88(\mathrm{LG}) \\
6 \cdot 83(\mathrm{JB}) \\
8 \cdot 11(\mathrm{LT}) \\
7 \cdot 15(\mathrm{GA}) \\
7 \cdot 48\end{array}$ & $\begin{array}{l}5 \cdot 57(\mathrm{JB}) \\
4 \cdot 60(\mathrm{~L} \cdot) \\
4 \cdot 00(\mathrm{GA}) \\
4 \cdot 81(\mathrm{~TB}) \\
5 \cdot 11(\mathrm{CD}) \\
6 \cdot 38(\mathrm{LG}) \\
5 \cdot 25\end{array}$ & $\begin{array}{l}4.83(\mathrm{GA}) \\
4 \cdot 36(\mathrm{~TB}) \\
5 \cdot 66(\mathrm{CD}) \\
4 \cdot 48(\mathrm{LG}) \\
4.90(\mathrm{JB}) \\
4 \cdot 32(\mathrm{LT}) \\
4 \cdot 76\end{array}$ & $\begin{array}{l}4 \cdot 74(\mathrm{LT}) \\
4 \cdot 46(\mathrm{GA}) \\
5 \cdot 30(\mathrm{~TB}) \\
4 \cdot 72(\mathrm{CD}) \\
4 \cdot 18(\mathrm{LG}) \\
5 \cdot 28(\mathrm{JB}) \\
4 \cdot 78\end{array}$ & $\begin{array}{l}3 \cdot 70(\mathrm{LG}) \\
2 \cdot 70(\mathrm{JB}) \\
2 \cdot 30(\mathrm{LT}) \\
3 \cdot 00(\mathrm{GA}) \\
4 \cdot 62(\mathrm{~TB}) \\
2 \cdot 90(\mathrm{CD}) \\
3 \cdot 20\end{array}$ & $\begin{array}{l}4 \cdot 43 \text { (CD) } \\
4 \cdot 26(\mathrm{LG}) \\
3 \cdot 30(\mathrm{JB}) \\
3 \cdot 30(\mathrm{LT}) \\
3 \cdot 38(\mathrm{GA}) \\
3 \cdot 30 \text { (TB) } \\
3 \cdot 66\end{array}$ \\
\hline
\end{tabular}

Initials of subjects are given in parentheses.

Table 5 Analysis of variance of log counts of Staph. aureus after treatment

\begin{tabular}{lll}
\hline & Degrees of freedom & Mean square \\
\hline Persons & 5 & $0.5455 \mathrm{~S}(\mathrm{P}<0.05>0.02)$ \\
Experiments & 5 & $0.4309 \mathrm{NS}$ \\
Treatments & 5 & $13.1758 \mathrm{~S}(\mathrm{P}<0.001)$ \\
Residual & 20 & 0.2010 \\
\hline
\end{tabular}

Analysis of variance of log counts of Ps. aeruginosa after treatment

\begin{tabular}{lcc}
\hline & Degrees of freedom & Mean square \\
\hline Persons & 5 & $0.3737 \mathrm{NS}$ \\
Experiments & 5 & $0.3820 \mathrm{NS}$ \\
Treatments & 5 & $14.0014 \mathrm{~S}(\mathrm{P}<0.001)$ \\
Residual & 20 & 0.2109 \\
\hline
\end{tabular}

method of application of the disinfectants, and method of recovery of the organisms after disinfection.

The choice of a test organism depends on its survival on the skin, safety, ease of identification on recovery medium, and response to different disinfectants. It was considered that at least one Gramnegative bacillus and one Gram-positive coccus would be required in a test.

Most Gram-negative bacilli die rapidly on drying, but $E$. coli showed a consistent number of survivors after drying on the skin for two minutes and is widely used in test methods in other countries. It was, therefore, included as the main test organism. Klebsiella aerogenes survives better on the skin than most Gram-negative bacilli and, in view of its increasing clinical significance (Casewell and Phillips, 1977), might be considered as a possible alternative test organism.

Staph. aureus is more sensitive to some antiseptics, for example, hexachlorophane and chlorhexidine, than Gram-negative bacilli and was initially chosen as the other test organism. It survives well on the skin but could not always be easily distinguished from other organisms in the resident flora. The phosphatase test was satisfactory but requires some experience. Preliminary tests with a tetracycline-resistant strain showed slight inhibition when the recovery medium contained 10 $\mu \mathrm{g} / \mathrm{ml}$ tetracycline. However, Staph. aureus was considered unacceptable when two subjects developed sepsis of the fingers in the second series of tests. A novobiocin-resistant, well-pigmented strain of Staph. saprophyticus was chosen as a safe alternative to Staph. aureus. Unfortunately, it was more sensitive than Staph. aureus to chlorhexidine detergent in both in-vivo and in-vitro tests and was therefore not suitable as a test organism. Further studies on other 
Table 6 Mean logarithmic reductions of test organisms after treatment

\begin{tabular}{|c|c|c|c|c|}
\hline & \multicolumn{4}{|c|}{ Mean log reduction factors after treatment (No. of subjects) } \\
\hline & Soap & Chlorhexidine detergent & Povidone-iodine detergent & $70 \%$ ethyl alcohol \\
\hline Staph. aureus 1 & $一$ & 一 & 一 & $\begin{array}{c}3.67 \pm 0.58 \\
(10)\end{array}$ \\
\hline Staph. aureus 2 & $\begin{array}{c}2.31 \pm 0.58 \\
(10)\end{array}$ & $2 \cdot 40 \underset{(11)}{ \pm 0.44}$ & $\begin{array}{c}3.02 \pm 0.41 \\
(10)\end{array}$ & - \\
\hline Staph. saprophyticus & $2.49 \underset{(12)}{ \pm 0.43}$ & $\begin{array}{c}3.78 \pm 0.69 \\
(10) \\
3.71 \pm 0.62 \\
(11)\end{array}$ & $\begin{array}{c}1.99 \pm 0.38 \\
(10) \\
2 \cdot 15 \pm 0.41 \\
(11)\end{array}$ & $\begin{array}{c}3.52 \pm 1.07 \\
(11) \\
* 3.51 \pm 0.82 \\
(10)\end{array}$ \\
\hline Esch. coli 2 & $\begin{array}{c}2.41 \pm 0.85 \\
(10)\end{array}$ & $\begin{array}{c}2.78 \pm 0.76 \\
(8) \\
2.86 \pm 0.73 \\
(10)\end{array}$ & $\begin{array}{c}2.76 \pm 0.78 \\
(10)\end{array}$ & $\begin{array}{c}3.40 \pm 0.79 \\
(10)\end{array}$ \\
\hline
\end{tabular}

*Isopropyl alcohol.

\pm Standard deviation.

organisms to find a suitable alternative to Staph. aureus are necessary.

The method and time of application of the disinfectant are also important, particularly with alcoholic solutions. In our studies with $70 \%$ alcohol in the clinical situation some unexplained high counts were obtained after treatment. Similar high counts were sometimes obtained in our preliminary laboratory experiments. Tests made with an alcoholic dye solution indicated that areas of the hands often remained untreated by the solution, particularly the tip of the thumb (Taylor, 1978). A standard method of application is, therefore, required for testing, but for routine purposes a less complicated method than that described for this test would be necessary. Although the studies with a dye suggested that adequate cover of all the surfaces of the hands was not necessarily related to duration of application, the duration of application of the disinfectant also has some relevance. The mean time for nurses' handwashing in wards was found to be 21 seconds and ranged from a few seconds to 108 seconds. Thirty seconds seemed to be a reasonable compromise, and our unpublished studies and those of other workers (Lowbury et al., 1964b; Mittermayer and Rotter, 1975) indicate that effectiveness is not greatly improved if the time is increased to one to two minutes.

Sampling of the finger-tips is easier than that of most other sites, and consistent results have been obtained by other workers with this method (Rotter et al., 1974). Finger-tips are also frequently contaminated in clinical practice. The number of surviving bacteria, particularly after alcoholic disinfection, was often very small. Sampling the whole volume of washings with a membrane filter is possible, but when this method is used a heavy growth of the normal resident flora is obtained. Rubbing the fingers on the base of a petri dish in $\mathbf{1 0}$ $\mathrm{ml}$ of broth also improves the sensitivity of the test (Rotter et al., 1974), although unpublished observations showed that the bowl and petri dish test usually gave comparable results (W. Koller and J.R. Babb, personal communication). Agar contact plates, used instead of washings for recovery of organisms, are useful for a quick assessment of effectiveness and for in-use clinical tests (Smylie $e t$ al., 1973; Ayliffe et al., 1975) but are insufficiently standardised for a comparison of preparations.

The meaning of any laboratory test in clinical terms is difficult to assess. Organisms applied to the skin artificially may behave differently from naturally acquired organisms (Ayliffe and Lowbury, 1969), and the method of application may affect the efficiency of disinfection (Lilly and Lowbury, 1978). In ward studies, hand sampling after the use of soap and water or $70 \%$ alcohol gave results rather similar to those obtained in this study (Ayliffe et al., 1975). Pathogens are not often present on the fingers in large numbers, but $10^{6}$ to $10^{7}$ Staph. aureus and Gram-negative bacilli have been recovered from nurses' hands after various nursing procedures. A reduction of $10^{2}(99 \%)$ obtained with soap and water (Lowbury et al., 1964a) is probably sufficient for most purposes, and Gram-negative bacilli die rapidly on dry skin. The antiseptic detergents were more effective than soap against some organisms and may have some value in special units, for example, special care baby units. $70 \%$ alcohol with or without chlorhexidine is more effective than the antiseptic detergents but requires care to ensure good coverage of the hands during the period before evaporation.

A standard test that measures the mean log reduction in numbers of organisms can be interpreted in different ways, depending on the beliefs of the country or person concerned. However, an internationally agreed interpretation should be possible when sufficient data are available from 
sampling hands of staff in clinical areas. A comparison of a standard soap and water wash and an application of $70 \%$ alcohol with that of an unknown agent should provide useful information. A test (Rotter et al., 1974) similar to the one described here has been proposed for possible use in European countries; it is hoped that other laboratories will carry out reproducibility studies on one of these tests after any necessary modification.

We thank Dr M. Rotter, Institute of Hygiene, Vienna, and Dr R. R. Marples, Public Health Laboratory Service, Colindale, for providing us with two of the test strains (E. coli and Staph. saprophyticus); the staff of the Hospital Infection Research Laboratory and the Microbiology Department, Dudley Road Hospital for taking part in the study; M. D. Wilkins, FIMLS, MRC Industrial Injuries and Burns Unit, Birmingham Accident Hospital for help with the statistical analysis; and Dr E. J. L. Lowbury for advice.

\section{References}

Ayliffe, G. A. J., Babb, J. R., Bridges, K., Lilly, H. A., Lowbury, E. J. L., Varney, J., and Wilkins, M. D. (1975). Comparison of two methods for assessing the removal of total organisms and pathogens from the skin. Journal of Hygiene, 75, 259-274.

Ayliffe, G. A. J., and Lowbury, E. J. L. (1969). Sources of gas gangrene in hospital. British Medical Journal, 2, 333-337.

Barber, M., and Kuper, S. W. A. (1951). Identification of Staphylococcus pyogenes by phosphatase reaction. Journal of Pathology and Bacteriology, 63, 65-68.

Casewell, M., and Phillips, I. (1977). Hands as route of transmission for Klebsiella species. British Medical Journal, 2, 1315-1317.

Deutsche Gesellschaft für Hygiene und Mikrobiologie (DGHM) (1972). Richtlinien für die Prüfung chemischer Desinfektionsmittel 3. Aufl. G. Fischer, Stuttgart.

Lilly, H. A., and Lowbury, E. J. L. (1978). Transient skin flora. Their removal by cleansing or disinfection in relation to their mode of deposition, Journal of Clinical Pathology, 31, 919-922.

Lowbury, E. J. L., Lilly, H. A., and Bull, J. P. (1960). Disinfection of the skin of operation sites. British Medical Journal, 2, 1039-44.

Lowbury, E. J. L., Lilly, H. A., and Bull, J. P. (1964a). Disinfection of hands: Removal of transient organisms. British Medical Journal, 2, 230-233.

Lowbury, E. J. L., Lilly, H. A., and Bull, J. P. (1964b). Methods for disinfection of hands and operation sites. British Medical Journal, 2, 531-536.

Männer, F., Rotter, M., and Mittermayrer, H. (1975). Verleichende Untersuchungen zur Keimgewinnung von der künstlich kontaminierter Hand. Zentralblatt für Bakteriologie, Parasitenkunde, Infektionskrankheiten, und Hygiene, Abt. 1: Orig. B160, 412-431.

Mittermayer, H., and Rotter, M. (1975). Vergleich der Wirkung von Wasser, einigen Detergentien und Äthylalkohol auf die transiente Flora der Hände. Zentralblatt für Bakteriologie Parasitenkunde, Infektionskrankheiten und Hygiene, Abt. 1: Orig. B160, 163-172.

Price, P. B. (1938). The bacteriology of normal skin; a new quantitative test applied to a study of the bacterial flora and the disinfection action of mechanical cleansing. Journal of Infectious Diseases, 63, 301-318.

Ricketts, C. R., Squire, J. R., Topley, E., and Lilly, H. A. (1951). Human skin lipids with particular reference to the self sterilising power of the skin. Clinical Science, 10, 89-111.

Rotter, M., Mittermayer, H., and Kundi, M. (1974). Untersuchungen zum Modell der künstlich kontaminierten Hand: Vorschlag für eine Prüfmethode. Zentralblatt für Bakteriologie Parasitenkunde, Infektionskrankheiten und Hygiene, Abt. 1: Orig. B159, 560581.

Smylie, H. G., Logie, J. R. C., and Smith, G. (1973). From Phisohex to Hibiscrub. British Medical Journal, 4, 586-589.

Taylor, L. J. (1978). An evaluation of handwashing techniques. Nursing Times, 74, 54-55, 108-110.

Requests for reprints to: Dr G. A. J. Ayliffe, Regional Health Service Infection Research Laboratory, Dudley Road Hospital, Dudley Road, Birmingham B18 7QH 